\title{
STATISTICS ON BANKRUPTCY OF COMPANIES IN POLAND
}

\author{
Sebastian Klaudiusz Tomezak \\ Wrocław University of Science and Technology, Wrocław, Poland \\ ORCID: 0000-0003-3528-3533; e-mail: sebastian.tomczak@pwr.edu.pl \\ (C) 2018 Sebastian Klaudiusz Tomczak \\ This is an open access article distributed under the Creative Commons Attribution-NonCommercial-NoDerivs license \\ (http://creativecommons.org/licenses/by-nc-nd/3.0/)
}

DOI: $10.15611 / \mathrm{ms} .2018 .3 .05$

JEL Classification: G01, G33

\begin{abstract}
The phenomenon of business failure in Poland came into being anew with the fall of the communist rule - it was the beginning of the 1990s, and the transition period from a centrally controlled market to a market economy was triggered. At that moment the market was a place where verification was being made regarding whether or not companies would be able to function, and consequently should they file for bankruptcy? Bankruptcy can be called a controlling device designed to eliminate the weakest links from the market, leaving the strongest players. This led to the creation of new statistical data, access to which has become easier over the years. This paper presents selected statistical data on bankruptcies of enterprises in Poland in the period 1990-2017. These data are presented by various credit information agencies by sector and region. However, these figures involve no relationship between the number of bankrupt enterprises and the number of operating ones. For this reason, the author calculated the statistical data, taking into account the relevant facts. The paper also introduces the business insolvency index and the newly established business index. The author suggested analyzing both of them in the analysis of bankruptcy data.
\end{abstract}

Keywords: bankruptcy, statistics, business, business insolvency index.

\section{Introduction}

Running a business under conditions of ever increasing competition with constantly evolving customer preferences involves uncertainty regarding "intentional" success. For that reason, companies need to continuously adapt to changes. Businesses that are unable to adapt are threatened with bankruptcy. This paper presents selected statistical information regarding the bankruptcy of enterprises in Poland over a twenty-seven year period. Although various credit information agencies furnish the data according to region and sector, the figures omit the relationship between the number of bankrupt enterprises and the number of operating ones. Such a connection is crucial to this paper, which is why the author incorporated it into the calculations of statistical information. Therefore, the purpose of the research is to compare the statistics on the number of bankrupt companies by testing the significance of the differences between the values of indicators of the bankrupt companies taking into account the number of operating companies, as well as the values of the indicators which do not incorporate such figures. The statistical significance will be examined by using ANOVA and t-Student tests. In addition, the article presents the business insolvency index and the newly established business index that, according to the author, will better reflect the number of default companies. The paper is organized as follows: literature review, methodology of research, results, discussion and conclusions.

\section{Literature review}

In the literature on the subject there are many statistics concerning the capital market, business entities, macroeconomics and other indicators. Above all, the government agencies provide official industry statistics, most notably reports about the gross domestic product (GDP), information about 
personal income, corporate profits, etc. In each country the names of the institutions are different, for example in the United States there is, among others, the Bureau of Economic Analysis (BEA), in Europe the European Statistical Office, in France the National Institute of Statistics and Economic Studies (Institut National de la Statistique et des Études Économiques), in Germany the Federal Statistical Office (Statistisches Bundesamt Deutschland), in Great Britain the Office for National Statistics and in Spain the National Institute of Statistics (Instituto Nacional de Estadistica). The statistics concerning companies, especially their bankruptcy, are published by the Ministry of Justice, the American Bankruptcy Institute, as well as by various credit information agencies that operate around the world, among them Dun\&Bradstreet, Coface, Creditreform and Euler Hermes.

In Poland the statistics on companies and their bankruptcy are also presented by the Central Statistical Office, the Ministry of Justice and by various credit information agencies, including Dun\&Bradstreet, Coface, Creditreform and Euler Hermes, for instance. The Coface reports include the number of announced bankruptcies (according to sector, region or legal form). In turn, the reports of Creditreform include also the number of insolvent companies per 10,000 operating companies on the market. On the other hand, the Dun\&Bradstreet reports incorporate the ratio of bankrupt companies in relation to the number of companies operating on the market. However, the bankruptcy statistics do not take into account the number of active companies in the sector or the region.

In Poland at the end of 2017, according to data provided by the Central Statistical Office, there were more than four million three hundred thousand operating businesses. More and more companies are operating in the market. Only in 2009 and 2011, the number of companies that shut down their business exceeded the ones being established ${ }^{1}$ (Figure 1). At the end of the analyzed period, the number of newly established companies was close to 362,000 , while the number of companies that deregistered from REGON was nearly 287,000 .

In analyzing the number of deregistered business entities, it is worth noting that not every bankrupt company or its creditors files for bankruptcy. There is often the silent death of businesses. Despite the fact that an entity went bankrupt, its liabilities may be paid from other sources, e.g. from the family funds of the entrepreneur [Mączyńska 2013]. As a result, the statistics of bankruptcy cases and announced bankruptcies are much lower than the number of closed-down businesses. Over the last 22 years (1996-2017), more than five million five hundred thousand companies were removed from the register, however the number of records of bankruptcy cases that in the period of transition (1990-2017) only exceeded a hundred twenty thousand (Figure 2). What is more, in the period after the transformation, access to data has been much larger and thus a more detailed analysis can be done year by year. Despite this, the records of bankruptcy cases are 45 times lower than the number of the defunct business entities from REGON register in the studied period.

For that reason the scarcity of statistics does not present a complete picture of bankruptcies, especially economic bankruptcies. This issue is characterized by insufficient knowledge and the highly unsatisfactory efficiency of bankruptcy proceedings, which translates into significant measurable and immeasurable damage to the economy and negative social consequences [Mączyńska 2013].

Nearly twenty percent of bankruptcy cases ended up with the declared bankruptcy of the company during the period considered. Such a low percentage of announced bankruptcy is influenced by many factors, for example enterprises do not have enough money to cover legal costs. In 2015, more than thirtythree percent of the cases of bankruptcy were rejected because of the lack of assets to cover the legal costs (this means that the companies had already been economically bankrupt). Nearly twenty-two percent of enterprises got their applications back, due to errors (they were paid improperly or had erroneous data) [Coface 2015]. While the number of announced business failure amounts to one-fifth of all bankruptcy cases, this is still a small percentage of announced bankruptcies; nevertheless, since 2008 the number of bankruptcies had been constantly growing until 2013, but the following year triggered a downwards trend in the number of bankruptcies (Figure 3). The KUKE forecast for 2018 agrees with this declining trend. One reason behind it could be the fact that since January 2016 the new restructuring law and the

\footnotetext{
1 The increase in the number of companies closing their operations in 2009 and 2011 had an impact upon the REGON update. In 2009 , the update was carried out on the basis of a survey (entities that did not report the cessation of activities have to submit an application to the statistical offices with the aim of removing the company from the REGON register). In 2011 this was carried out on the basis of information obtained from the Personal Identity Number Register of deceased people and the information from the National Court Register of entities removed from the National Court Register.
} 


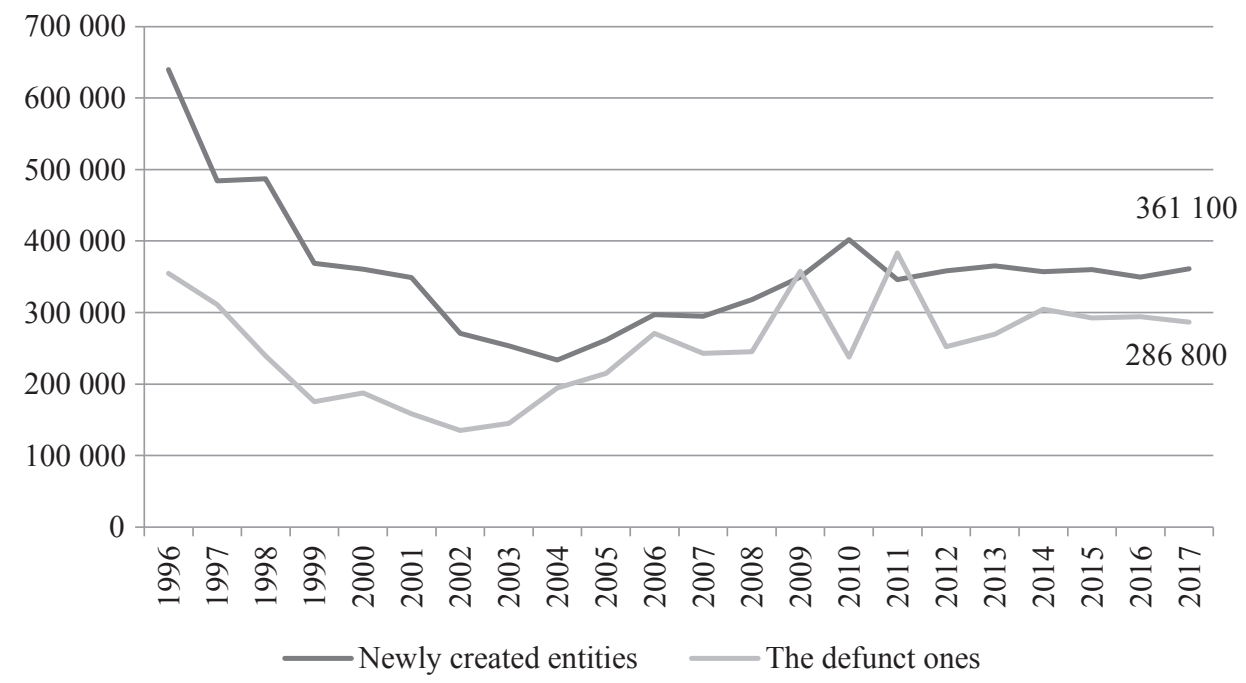

Fig. 1. Newly created entities and the defunct ones in the national economy from 1996 to 2017

Source: own work based on data from the [Central Statistical Office Reports].

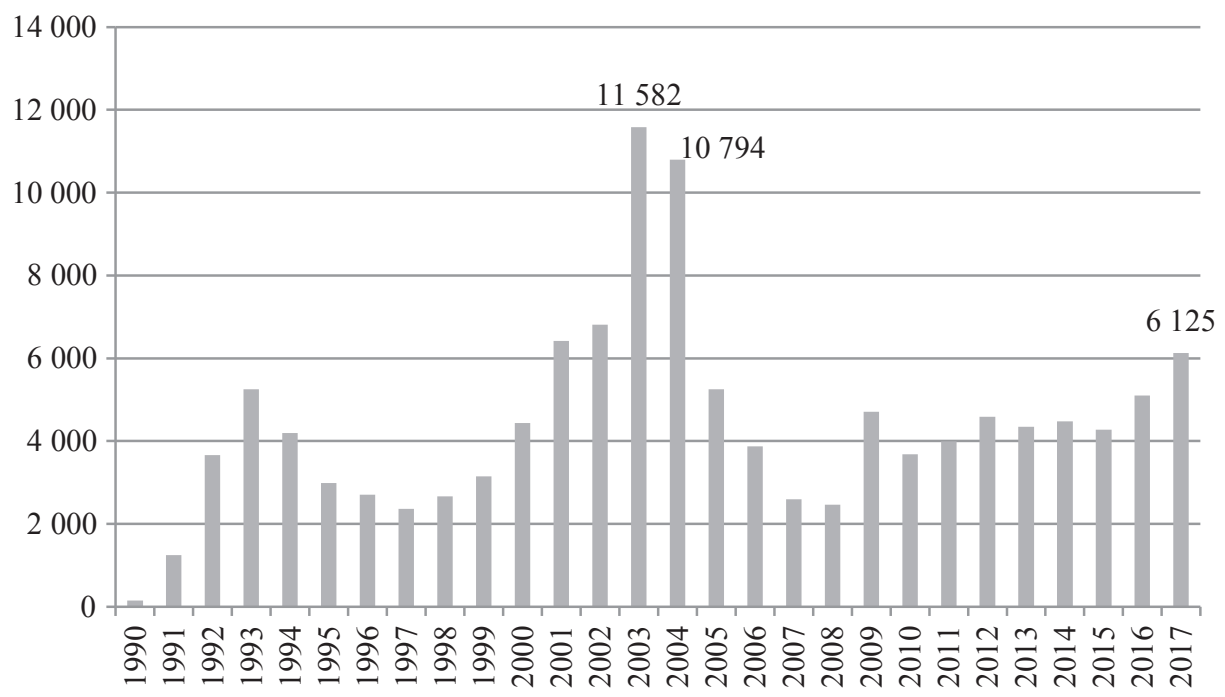

Fig. 2. Records of bankruptcy cases in the courts in the period between 1990 and 2017

Source: own work based on data from the [Ministry of Justice].

revised bankruptcy law have been in force. Thanks to novel restructuring, the debtor has four ways to conclude an agreement with creditors that will allow the company to survive (Article 2, the restructuring law 2015). Under new amendments to the bankruptcy law, creditors have a greater impact on the course of the proceedings (the bankruptcy law, PART III, participants in the proceedings, creditors). In 2018 Hermes expected stagnation rather than further improvement in the number of bankruptcies. They even foresee a symbolic increase in the numbers for Poland [Euler Hermes 2018].

Analyzing the number of declared bankruptcies presented in Figure 3, cyclical fluctuations can be ob- served that are related to the economic situation. The largest number occurred in 2002 during the economic crisis. Euler Hermes predicts that in 2018 this figure will be around two times lower. Due to the fact that the number of bankruptcies does not exceed a thousand and the number of shut-down businesses is close to three hundred thousand, one can say that the rate of announced bankruptcies in relation to the total REGON deregistered firms is negligible. The negligible value of this ratio indicates that the statistical data on announced bankruptcies do not represent the number of economic bankruptcies in the national economy.

There are many reasons for business failure. According to reports by: Coface, from 2007, 2011, 2012, 


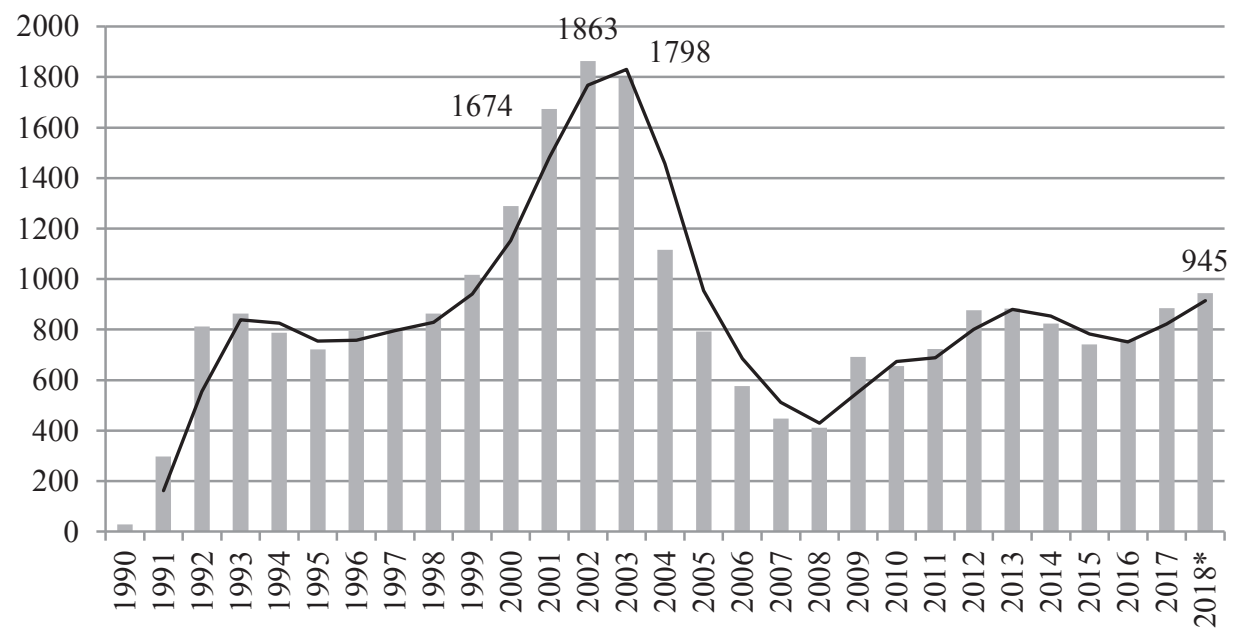

Fig. 3. The number of bankruptcy court rulings announced between 1990 and 2017

Source: own work based on data from the Ministry of Justice, Coface and KUKE reports.

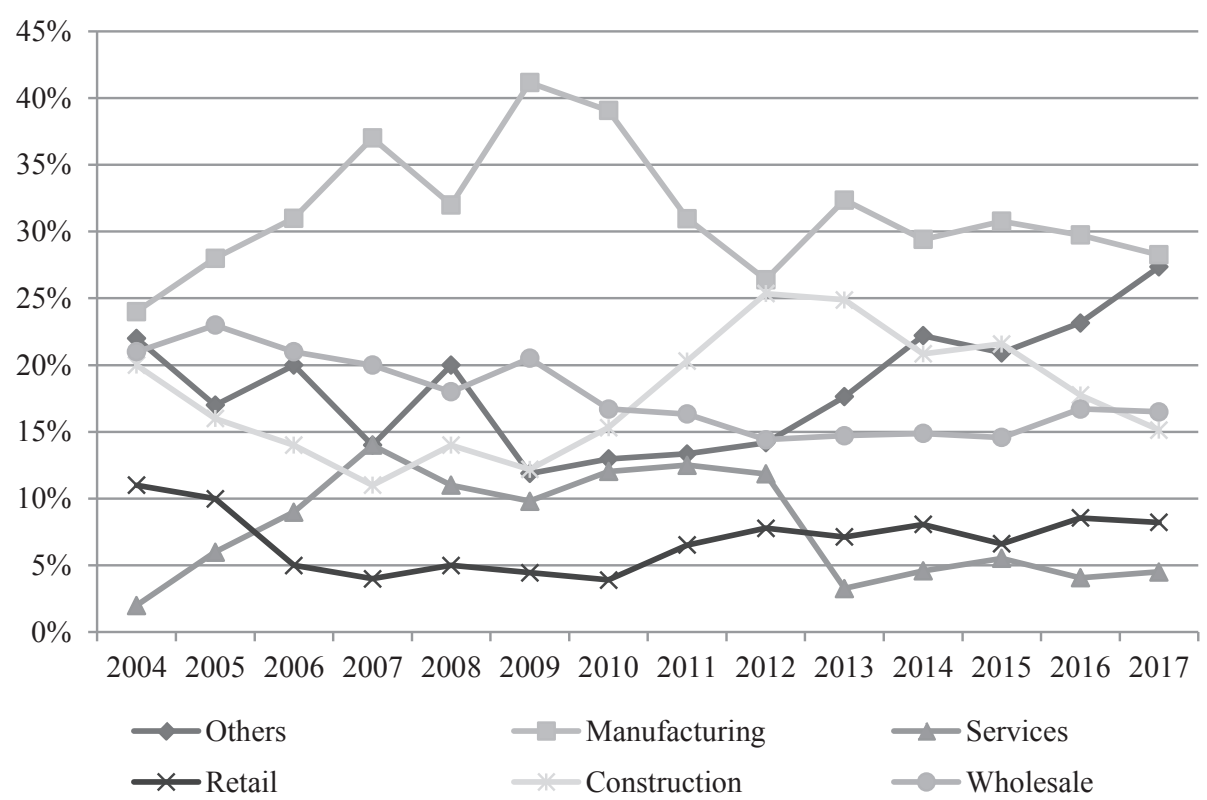

Fig. 4. Bankruptcy of enterprises by sector in the relevant period from 2004 to 2017

Source: own work based on [Coface 2007, 2011-2017].

2013, 2014 and 2015, [Euler Hermes] from 2009, 2012, 2013 and 2014 and [KUKE] from 2012 and 2013, there have been several sources of corporate bankruptcy in recent years: liquidity problems (some enterprises were characterized by a lack of liquidity and others by an excess [Tomczak 2014a]), decline in sales, too high a share of foreign capital in total assets, delays in payment, exchange rates and the generation of losses of the core business [Tomczak 2014b]. On the other hand, the main creditors of insolvent compa- nies include: suppliers, the Social Insurance Institution, banks and lawyers [Nowara, Szarzec 2004].

Most companies in the manufacturing sector have gone bankrupt in Poland since 2004 (Figure 4).

Apart from the manufacturing sector, the highest number of announced bankruptcy of economic entities resides in the sectors of wholesale and construction during the analyzed period. In addition, in Western Europe, ${ }^{2}$ unlike in Poland, the largest business failures occur in the service sector. These countries have

\footnotetext{
${ }^{2}$ According to Creditreform, Western Europe includes the following countries: Austria, Belgium, Denmark, Germany, Finland, France, Greece, Great Britain, Ireland, Italy, Luxembourg, The Netherlands, Norway, Portugal, Sweden, Switzerland and Spain.
} 


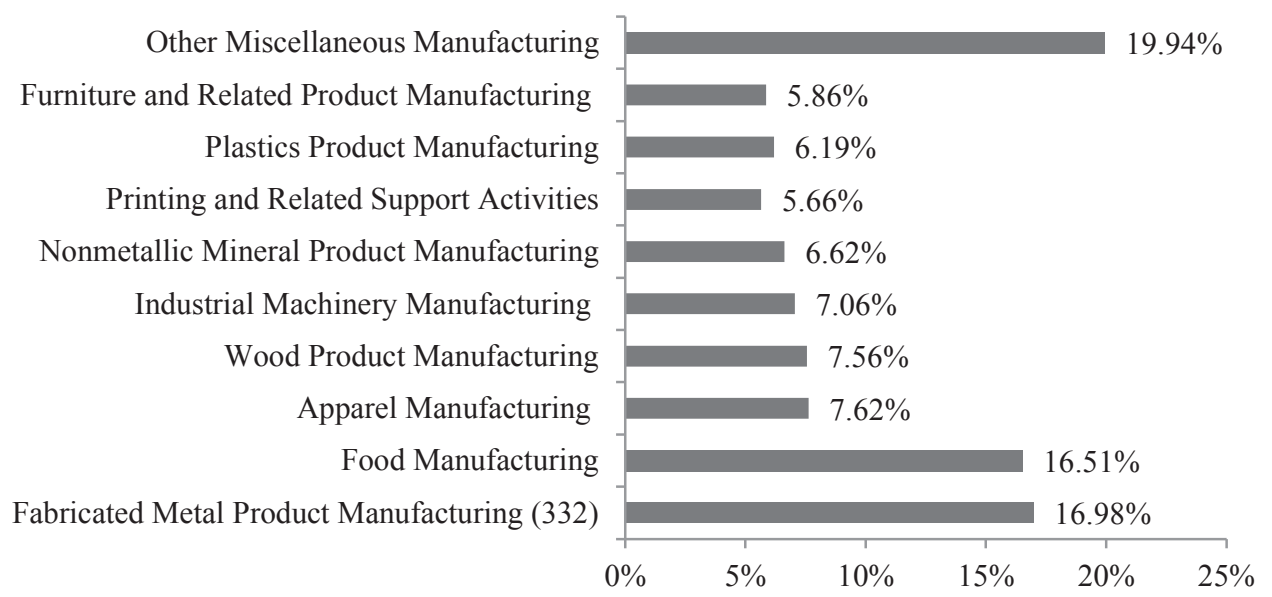

Fig. 5. The share of bankruptcies in the manufacturing sector in the period 2005-2017

Source: own work based on [Coface 2007, 2011-2017].

Table 1. Share of bankrupt companies in each province in the period 2000-2017

\begin{tabular}{|l|c|c|c|c|c|c|c|c|c|}
\hline \multicolumn{1}{|c|}{ Voivodeships } & 2000 & $\ldots$ & 2008 & 2009 & 2010 & $\ldots$ & 2015 & 2016 & 2017 \\
\hline Dolnośląskie & $14.00 \%$ & $\ldots$ & $10.71 \%$ & $12.45 \%$ & $11.76 \%$ & $\ldots$ & $9.45 \%$ & $12.63 \%$ & $11.07 \%$ \\
\hline Kujawsko-Pomorskie & $6.95 \%$ & $\ldots$ & $4.87 \%$ & $6.80 \%$ & $6.41 \%$ & $\ldots$ & $6.75 \%$ & $4.34 \%$ & $4.29 \%$ \\
\hline Lubelskie & $5.79 \%$ & $\ldots$ & $7.06 \%$ & $4.92 \%$ & $2.60 \%$ & $\ldots$ & $3.37 \%$ & $4.61 \%$ & $4.86 \%$ \\
\hline Lubuskie & $1.79 \%$ & $\ldots$ & $1.70 \%$ & $2.89 \%$ & $1.07 \%$ & $\ldots$ & $2.16 \%$ & $2.37 \%$ & $2.03 \%$ \\
\hline Mazowieckie & $13.37 \%$ & $\ldots$ & $22.14 \%$ & $17.08 \%$ & $20.46 \%$ & $\ldots$ & $22.27 \%$ & $19.08 \%$ & $20.79 \%$ \\
\hline Małopolskie & $4.00 \%$ & $\ldots$ & $4.87 \%$ & $7.67 \%$ & $7.94 \%$ & $\ldots$ & $8.77 \%$ & $10.39 \%$ & $5.88 \%$ \\
\hline Opolskie & $2.42 \%$ & $\ldots$ & $1.46 \%$ & $0.43 \%$ & $1.68 \%$ & $\ldots$ & $1.08 \%$ & $1.84 \%$ & $2.15 \%$ \\
\hline Podkarpackie & $3.79 \%$ & $\ldots$ & $4.38 \%$ & $4.34 \%$ & $3.51 \%$ & $\ldots$ & $3.91 \%$ & $4.34 \%$ & $3.95 \%$ \\
\hline Podlaskie & $3.68 \%$ & $\ldots$ & $0.97 \%$ & $0.87 \%$ & $1.07 \%$ & $\ldots$ & $0.94 \%$ & $2.63 \%$ & $3.28 \%$ \\
\hline Pomorskie & $4.32 \%$ & $\ldots$ & $2.92 \%$ & $2.60 \%$ & $3.21 \%$ & $\ldots$ & $4.59 \%$ & $3.03 \%$ & $4.75 \%$ \\
\hline Warmińsko-Mazurskie & $6.95 \%$ & $\ldots$ & $5.84 \%$ & $3.33 \%$ & $3.82 \%$ & $\ldots$ & $3.78 \%$ & $2.50 \%$ & $4.63 \%$ \\
\hline Wielkopolskie & $9.79 \%$ & $\ldots$ & $3.65 \%$ & $6.51 \%$ & $8.24 \%$ & $\ldots$ & $9.58 \%$ & $7.50 \%$ & $8.81 \%$ \\
\hline Zachodniopomorskie & $6.84 \%$ & $\ldots$ & $8.27 \%$ & $8.54 \%$ & $8.85 \%$ & $\ldots$ & $6.61 \%$ & $5.79 \%$ & $5.88 \%$ \\
\hline Lódzkie & $4.63 \%$ & $\ldots$ & $3.41 \%$ & $4.92 \%$ & $3.97 \%$ & $\ldots$ & $2.83 \%$ & $2.89 \%$ & $3.39 \%$ \\
\hline Śląskie & $10.11 \%$ & $\ldots$ & $15.33 \%$ & $15.05 \%$ & $14.20 \%$ & $\ldots$ & $11.47 \%$ & $14.08 \%$ & $12.66 \%$ \\
\hline Świętokrzyskień & $1.58 \%$ & $\ldots$ & $2.43 \%$ & $1.59 \%$ & $1.22 \%$ & $\ldots$ & $2.43 \%$ & $1.97 \%$ & $1.58 \%$ \\
\hline
\end{tabular}

Source: own work based on [Coface 2007, 2011-2017; http://www.portal-bankrut.pl/informacja.php?kto=\&tytul=\&sekcja1=upadlosci/ upadlosci_polska.php].

a more developed service sector, in contrast to Poland. Due to the most frequently announced bankruptcies being in the manufacturing industry, Figure 5 shows the bankruptcy figures in this industry, divided up into branches.

In the period in question, the food manufacturing companies and the metal manufacturing companies predominantly filed for bankruptcy. Figures differ from region to region in Poland. Thus, Table 1 shows the share of bankrupt companies in each province in the period 2000-2017.

The most frequently occurring bankruptcies were recorded for the Mazowieckie, Śląskie i Dolnośląskie voivodeships (Figure 6). The total share of bankrupt companies in each province in the last 18 years (2000-2017) does appear to confirm this.

According to Coface reports, the highest number of bankrupt companies reflects the largest number of registered businesses in each province [Coface 2012-2017], but this statement seems not to be true since the figures presented by, among others, Coface, do not include the relationship between the number of bankrupt enterprises and the number of operating enterprises. 


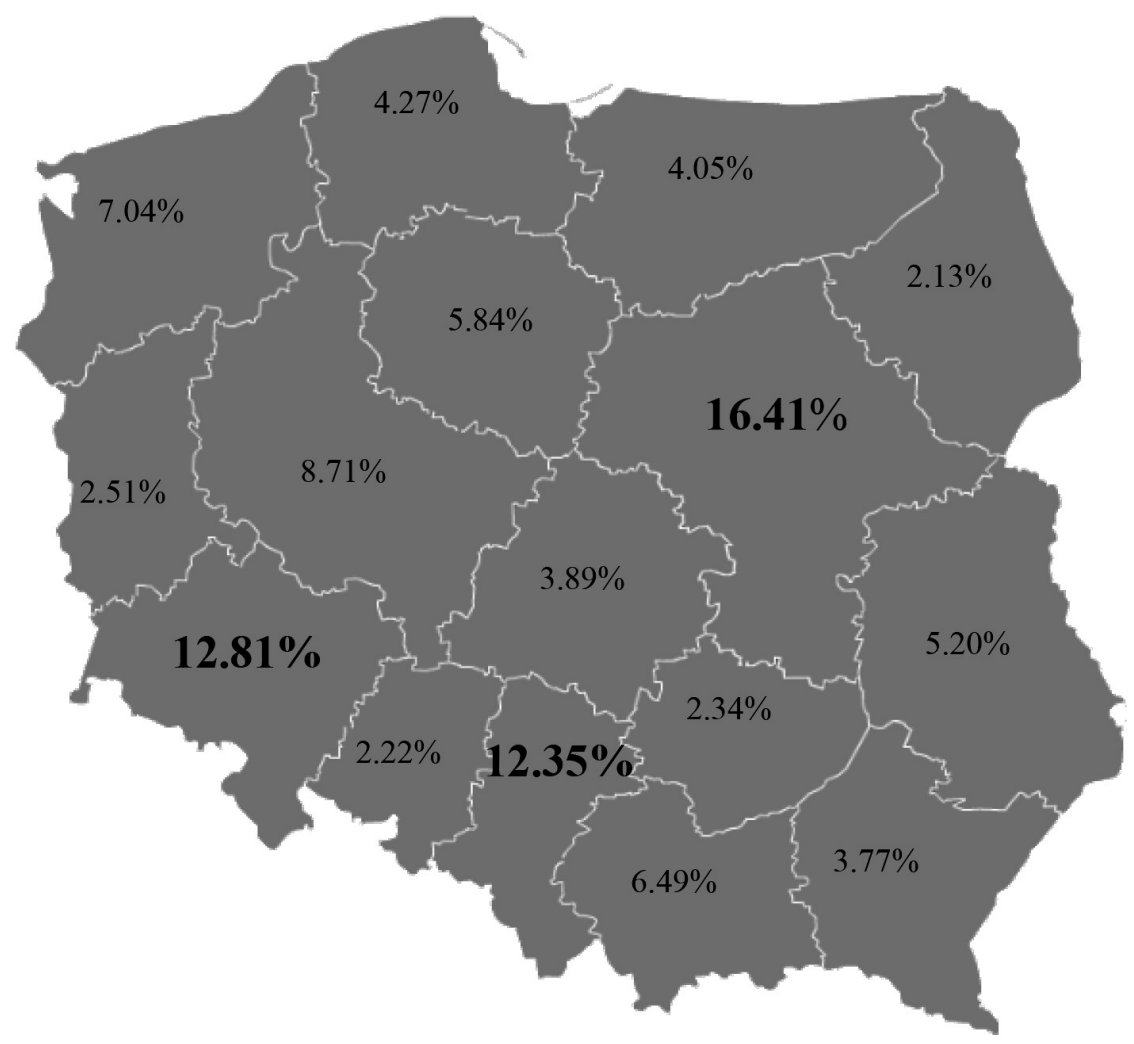

Fig. 6. Share of bankrupt companies in each voivodeship in the period 2000-2017

Source: own work based on [Coface 2007, 2011-2017; http://www.portal-bankrut.pl/informacja.php?kto=\&tytul=\&sekcja1=upadlosci/ upadlosci_polska.php].

\section{Methodology of research and data}

So far, statistics on bankruptcies of enterprises in Poland that have been presented by various credit information agencies do not exactly reflect the actual financial situation of enterprises. The statistical data neglect the relationship between the number of bankrupt and operating firms. The reports of Coface, KUKE and Euler Hermes express statistical data on bankruptcy by industry and province. In each report the ratio of the bankruptcy of companies in a given industry / region to the total number of insolvent companies is presented. This way of counting does not give a complete picture of bankruptcies by sector and voivodeship, because the number of companies operating in various sectors / voivodeships varies. Moreover, the statistics presented by the Coface, KUKE, Euler Hermes and Creditreform are different.

Therefore the aim of the study is to analyze the statistics concerning the number of bankrupt businesses by the verification of the significance of the differences between the values of ratios of the bankrupt businesses, bearing in mind the number of operating businesses and the values of the ratios which do not incorporate such figures as well as the values of the number of bankrupt companies given by Coface, KUKE, Euler Hermes and Creditreform.

The statistical significance will be checked using the t-Student test. In addition, the paper introduces the business insolvency index (total deleted companies from REGON in relation to the total operating ones), which, in the opinion of the author, will better express the insolvency of companies.

The research objective formulated in this way will answer the following research questions:

1. Are the differences between the values of the number of bankrupt companies given by Coface, KUKE, Euler Hermes and Creditreform statistically significant?

2. Are the differences between the values of the ratio of bankrupt firms in the sector (manufacturing, services, retail, construction, wholesale) to the general businesses operating in the sector and the values of the ratio bankruptcy of enterprises by sector (manufacturing, services, retail, construction, wholesale) statistically significant?

3. Are the differences between the values of the total percentage of bankrupt enterprises taking into account the existing enterprises in all the above mentioned regions (Dolnośląskie, Kujawsko-Pomorskie, 
Lubelskie, Lubuskie, Łódzkie, Małopolskie, Mazowieckie, Opolskie, Podkarpackie, Podlaskie, Pomorskie, Śląskie, Świętokrzystkie, Warmińsko-Mazurskie, Wielkopolskie, Zachodniopomorskie) and the ratio of total share of bankrupt companies in each of them (Dolnośląskie, Kujawsko-Pomorskie, Lubelskie, Lubuskie, Łódzkie, Małopolskie, Mazowieckie, Opolskie, Podkarpackie, Podlaskie, Pomorskie, Śląskie, Świętokrzystkie, Warmińsko-Mazurskie, Wielkopolskie, Zachodniopomorskie) statistically significant?

In order to analyze the differences between the values of ratios of the bankrupt businesses which include (or not) the number of operating businesses, the ANOVA and t-Student test for independent samples were used (the hypothesis will be tested against the significance of 0.05 ). This test is a commonly adopted method for analyzing dissimilarities between the averages in the two groups (in this particular case differences in the averaged values in the defined intervals of the values of the indicator). This test can assess whether the existing difference in the averages of the examined groups is statistically relevant. The t-Student test was applied through the use of the Statistica suite. The study period covers the years 1990-2017. The choice of this particular period is related to the availability of financial data of the enterprises in the analyzed period.

\section{Results}

First, the statistics concerning the number of bankrupt companies in Poland presented by the credit information agency were tested, next the number of bankrupt entities in the sector was divided by the number of entities operating in the sector, and after that the number of bankrupt entities in the particular region was divided by the number of entities operating in the particular region. Finally, the business insolvency index and the newly established business index were introduced. The results of the study are presented in the figures and tables and will provide answers to the research questions.

The statistics on the number of bankrupt companies in Poland vary slightly from credit information agency to credit information agency (Figure 7). This is due to the different way of counting the number of bankrupt companies. Coface has adopted a slightly different reference period referring in the reports to the historical data with their fixed date pointing to the end of December. For example, the 2017 report states that the data are up to date on 28 December.

However, the differences observed in the values in individual reports are statistically insignificant. The statistical significance of the differences in the samples was tested using the ANOVA test. This means that the method of reporting data on the number of bankrupt enterprises in Poland is not statistically relevant. This statement is the answer to the first research question.

In Figure 4, the statistics are calculated by dividing the number of bankrupt enterprises in the sector by the total number of bankruptcies. This way of counting does not give a complete picture of bankruptcies by sector because the number of companies operating in various sectors is different. In Figure 8 the statistics have taken into account the number of active companies in the sector. Taking into consideration the

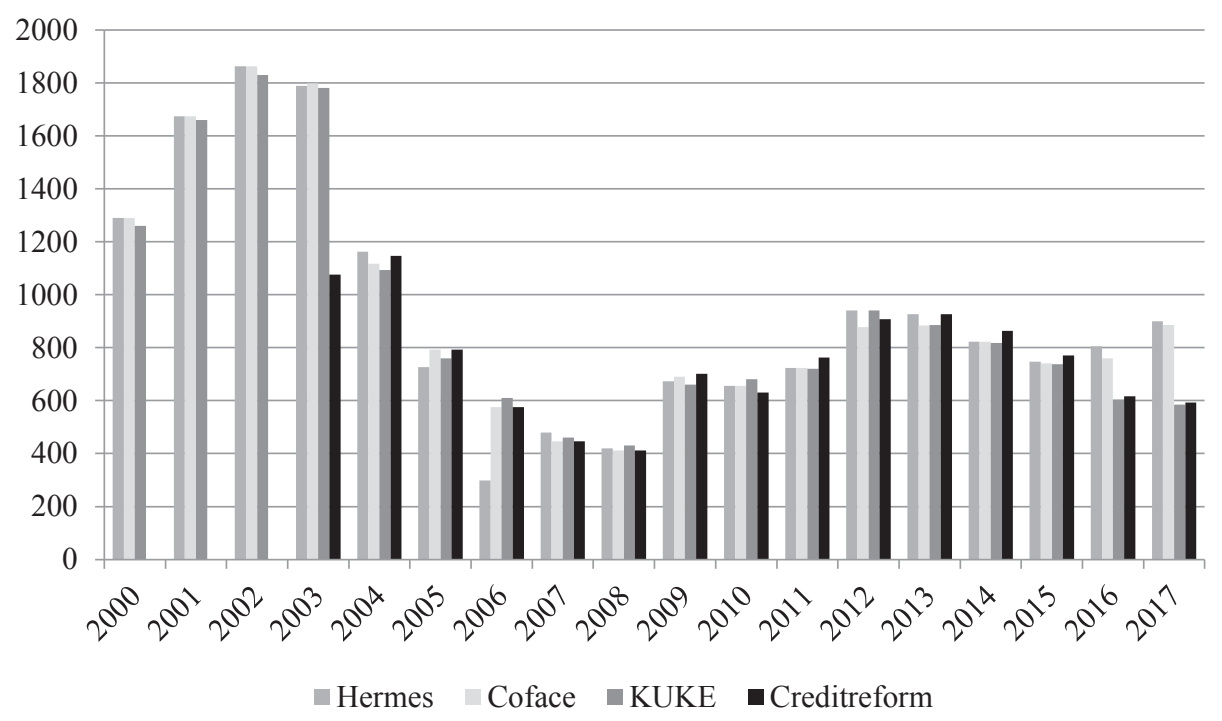

Fig. 7. The number of bankruptcy court rulings announced according to reports by Euler Hermes, Coface, KUKE and Creditreform Source: own work based on the reports of Euler Hermes, Coface and KUKE. 


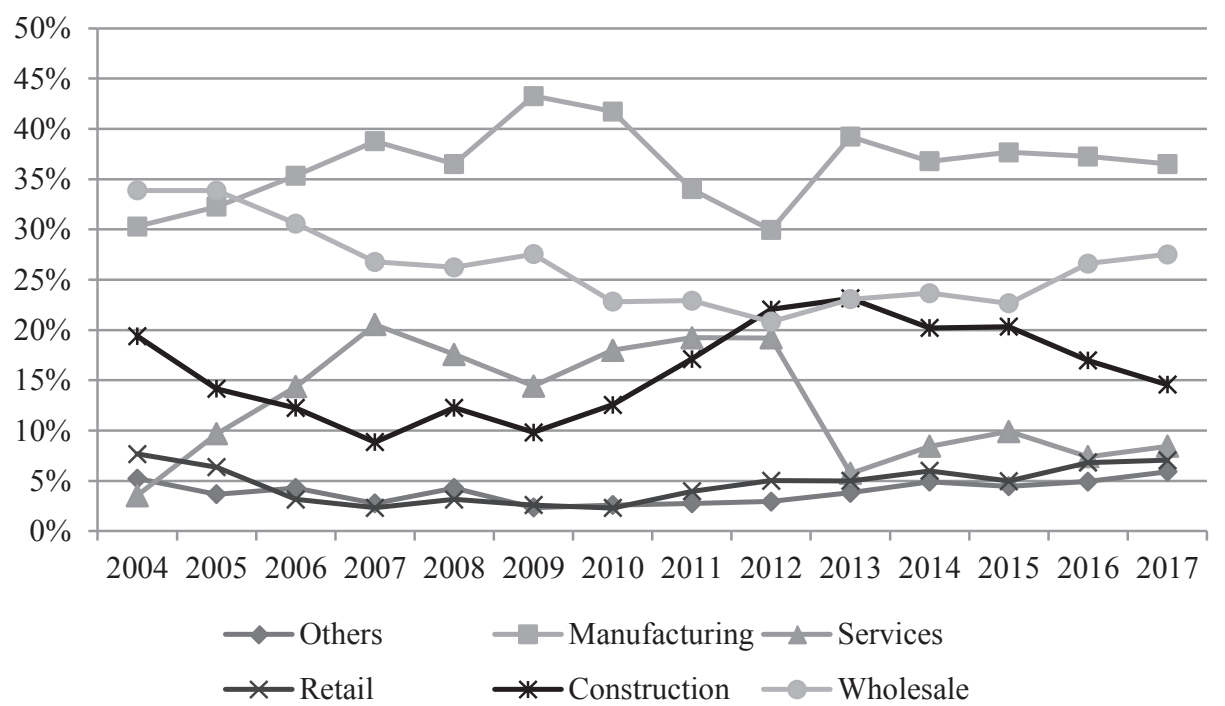

Fig. 8. The ratio of bankrupt firms in the industry to general businesses operating in the industry

Source: own work based on [Coface 2007, 2011-2017; Central Statistical Office Reports; Central Statistical Office].

Table 2. The $t$-Student test for independent samples by sectors

\begin{tabular}{|l|c|c|c|c|c|c|c|c|c|c|c|}
\hline $\begin{array}{c}\text { Group 1 vs } \\
\text { Group 2 }\end{array}$ & $\begin{array}{c}\text { Mean } \\
\text { group 1 }\end{array}$ & $\begin{array}{c}\text { Mean } \\
\text { group 2 }\end{array}$ & $t$-value & $\mathrm{df}$ & $\mathrm{p}$ & $\begin{array}{c}\text { Valid N } \\
\text { group 1 }\end{array}$ & $\begin{array}{c}\text { Valid N } \\
\text { group 2 }\end{array}$ & $\begin{array}{c}\text { Std. Dev. } \\
\text { Group 1 }\end{array}$ & $\begin{array}{c}\text { Std. Dev. } \\
\text { Group 2 }\end{array}$ & F-ratio Var. & $\mathrm{p}$ Var. \\
\hline Manufacturing & 0.31 & 0.36 & -3.02 & 26 & 0.01 & 14 & 14 & 0.05 & 0.04 & 1.52 & 0.46 \\
\hline Services & 0.08 & 0.13 & -2.55 & 26 & 0.02 & 14 & 14 & 0.04 & 0.06 & 2.01 & 0.22 \\
\hline Retail & 0.07 & 0.05 & 2.76 & 26 & 0.01 & 14 & 14 & 0.02 & 0.02 & 1.42 & 0.53 \\
\hline Construction & 0.18 & 0.16 & 1.03 & 26 & 0.31 & 14 & 14 & 0.05 & 0.05 & 1.03 & 0.96 \\
\hline Wholesale & 0.18 & 0.26 & -6.43 & 26 & 0.00 & 14 & 14 & 0.03 & 0.04 & 2.08 & 0.20 \\
\hline
\end{tabular}

Source: own work based on [Coface 2007, 2011-2017; Central Statistical Office Reports] by using Statistica.

number of operating companies in each sector, this will answer the second research question.

The statistics in Figure 4 and Figure 8 do not differ very much from each other. Mostly manufacturing companies have gone bankrupt in the last decade. However, the share of wholesale trade enterprises in the total number of bankruptcies has increased significantly and at the end of 2017 it reached the value of $27.52 \%$. The differences between the values of the ratio of bankrupt firms in the sector (manufacturing, services, retail, construction, wholesale) to the general businesses operating in the sector and the values of the ratio bankruptcy of enterprises by sector (manufacturing, services, retail, construction, wholesale) were tested to check their statistical significance (Table 2).

By analyzing the result of the $t$-Student test, it can be seen that only the values of the construction sector do not differ significantly between themselves, while the values among other sectors are statistically significant. For this reason the method that includes counting the businesses operating in each sector in the bankruptcy data is the right one because it provides a complete picture of bankruptcy in various industries. This is the explanation of the answer to the second research question.

Bearing in mind the number of operating companies in an individual region, Figure 9 shows the results of the research that include the number of bankrupt companies in relation to the registered companies in the region. The analysis of Figure 9 and the results of the $t$-Student test will answer the last research question.

The results of research shown in Figure 9 are significantly different from the ones used in the statistics presented in Figure 6 . In the last 18 years, more companies went bankrupt in Lower Silesia (accounting for $8.56 \%$ of the total companies operating in the country) ${ }^{3}$ than in Mazowieckie (which accounts

\footnotetext{
3 The percentage of enterprises being run in a particular voivodeship to all companies operating in the economy refers to Central Statistical Office data from 2017.
} 


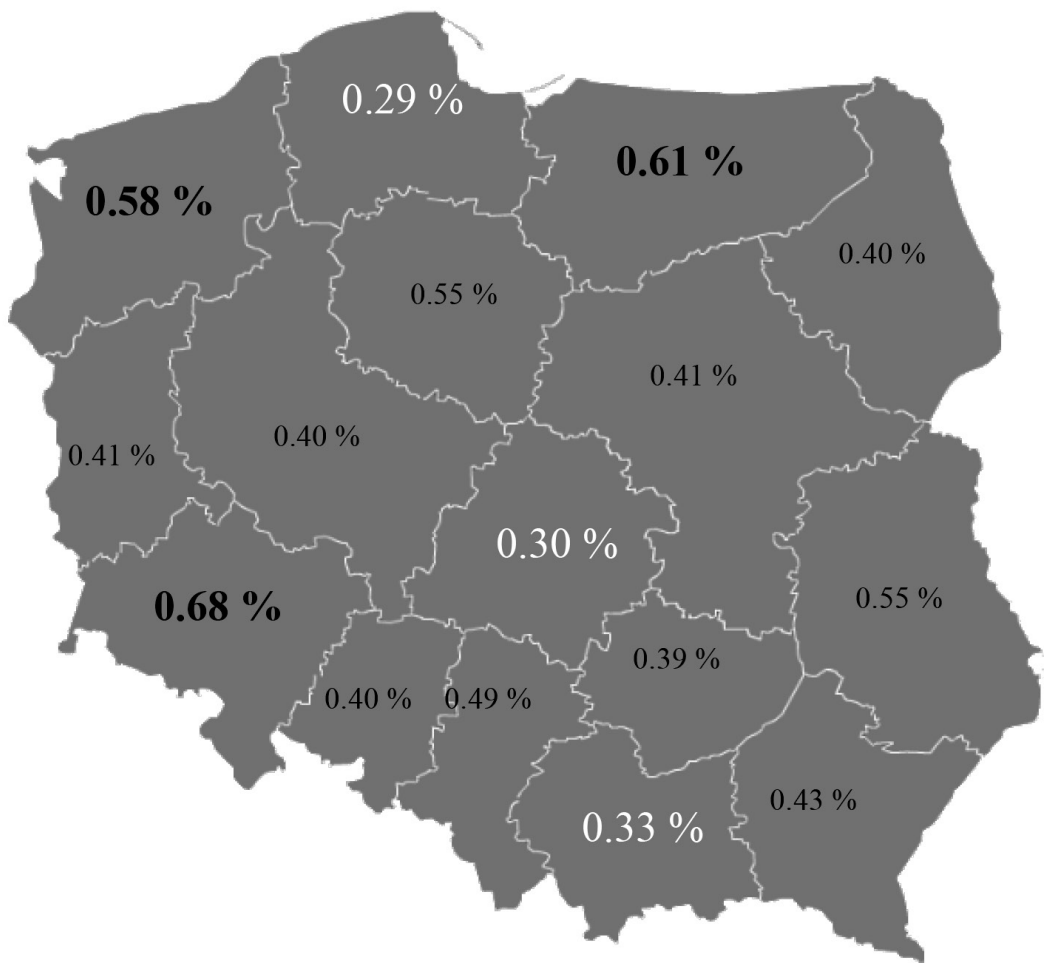

Fig. 9. The total percentage of bankrupt enterprises taking into account the existing enterprises in the region over a period of 18 years (from 2000 to 2017)

Source: own work based on [Coface 2007, 2011-2017; http://www.portal-bankrut.pl/informacja.php?kto=\&tytul=\&sekcja1=upadlosci/ upadlosci_polska.php; Central Statistical Office Reports; Central Statistical Office].

Table 3. The $t$-Student test for independent samples by voivodeships

\begin{tabular}{|c|c|c|c|c|c|c|c|c|c|c|c|}
\hline Group 1 vs Group 2 & $\begin{array}{l}\text { Mean } \\
\text { group } 1\end{array}$ & $\begin{array}{l}\text { Mean } \\
\text { group } 2\end{array}$ & $t$-value & $\mathrm{df}$ & $\mathrm{p}$ & $\begin{array}{l}\text { Valid N } \\
\text { group } 1\end{array}$ & $\begin{array}{l}\text { Valid N } \\
\text { group } 2\end{array}$ & $\begin{array}{c}\text { Std. Dev. } \\
\text { Group } 1\end{array}$ & $\begin{array}{l}\text { Std. Dev. } \\
\text { Group } 2\end{array}$ & $\begin{array}{l}\text { F-ratio } \\
\text { Var. }\end{array}$ & $\mathrm{p}$ Var. \\
\hline Dolnośląskie & 0.12 & 0.00 & 24.92 & 34 & 0.00 & 18 & 18 & 0.02 & 0.00 & 8571.43 & 0.0 \\
\hline Kujawsko-Pomorskie & 0.06 & 0.00 & 20.04 & 34 & 0.00 & 18 & 18 & 0.01 & 0.00 & 5685.88 & 0.0 \\
\hline Lubelskie & 0.05 & 0.00 & 8.69 & 34 & 0.00 & 18 & 18 & 0.03 & 0.00 & 18254.44 & 0.0 \\
\hline Lubuskie & 0.02 & 0.00 & 7.58 & 34 & 0.00 & 18 & 18 & 0.01 & 0.00 & 6184.94 & 0.0 \\
\hline Mazowieckie & 0.18 & 0.00 & 18.23 & 34 & 0.00 & 18 & 18 & 0.04 & 0.00 & 318785.1 & 0.0 \\
\hline Małopolskie & 0.07 & 0.00 & 12.24 & 34 & 0.00 & 18 & 18 & 0.02 & 0.00 & 87739.65 & 0.0 \\
\hline Opolskie & 0.02 & 0.00 & 6.56 & 34 & 0.00 & 18 & 18 & 0.01 & 0.00 & 4719.25 & 0.0 \\
\hline Podkarpackie & 0.04 & 0.00 & 25.42 & 34 & 0.00 & 18 & 18 & 0.01 & 0.00 & 2673.09 & 0.0 \\
\hline Podlaskie & 0.02 & 0.00 & 7.95 & 34 & 0.00 & 18 & 18 & 0.01 & 0.00 & 4518.13 & 0.0 \\
\hline Pomorskie & 0.04 & 0.00 & 17.48 & 34 & 0.00 & 18 & 18 & 0.01 & 0.00 & 8189.97 & 0.0 \\
\hline Warmińsko-Mazurskie & 0.04 & 0.00 & 12.60 & 34 & 0.00 & 18 & 18 & 0.01 & 0.00 & 3500.63 & 0.0 \\
\hline Wielkopolskie & 0.08 & 0.00 & 14.20 & 34 & 0.00 & 18 & 18 & 0.02 & 0.00 & 21976.14 & 0.0 \\
\hline Zachodniopomorskie & 0.07 & 0.00 & 16.33 & 34 & 0.00 & 18 & 18 & 0.02 & 0.00 & 11183.53 & 0.0 \\
\hline Łódzkie & 0.04 & 0.00 & 17.17 & 34 & 0.00 & 18 & 18 & 0.01 & 0.00 & 12692.15 & 0.0 \\
\hline Śląskie & 0.12 & 0.00 & 16.32 & 34 & 0.00 & 18 & 18 & 0.03 & 0.00 & 42771.74 & 0.0 \\
\hline Swiętokrzyskie & 0.02 & 0.00 & 11.21 & 34 & 0.00 & 18 & 18 & 0.01 & 0.00 & 1637.85 & 0.0 \\
\hline
\end{tabular}

Source: own work based on [Coface; Central Statistical Office Reports]. 
for $18.78 \%$ of all companies operating in the country). The two regions, Warmińsko-Mazurskie (2.91\%) and Zachodniopomorskie (5.18\%), rank second and third. On the other hand, the most rarely occurring bankruptcies were recorded in Pomorskie $(6.82 \%)$, Łódzkie (5.71\%) and Małopolskie1 (8.82\%). Based on the results, it cannot be said that most bankruptcies occur in the provinces with the largest number of registered companies, as the Coface report declares. It is worth adding that the specific nature of the region influences the number of bankruptcies of enterprises in a given voivodeship. The results are not dissimilar to the studies submitted by Antonowicz [2015]. However, his studies cover a much shorter period of time (2007-2013).

The differences between the values of the total percentage of bankrupt enterprises taking into account the existing enterprises in the studied regions and the ratio of total share of bankrupt companies in each of them were tested to analyze the statistical significance (Table 3).

Analyzing the results of the $t$-Student test presented in Table 3, it can be pointed out that the values differ significantly between themselves. Thus, the method that includes counting the businesses operating in each region in the bankruptcy data is very useful because it shows a full picture of bankruptcy in individual provinces. This answers the last research question.

Due to the fact that both the records of bankruptcy cases in the courts as well as the bankruptcies announced do not reflect the complete picture of bankruptcies, especially economic bankruptcies, the business insolvency index is presented below. The presentation of this indicator aims to initiate a discussion as to whether this indicator will better reflect the number of insolvency of enterprises in Poland or not.

$$
\text { The business insolvency index }=\frac{\begin{array}{c}
\text { The defunct companies } \\
\text { from REGON }
\end{array}}{\begin{array}{c}
\text { Total number of entities } \\
\text { of the national economy }
\end{array}}
$$

This indicator is the ratio of the number of defunct companies from REGON to the total number of operating entities in the economy. The index values are expressed in percentages and show what percentage of businesses is shut down every year. The index should be compared to the newly created business index. This indicator shows what the percentage of newly created companies is. Comparing these two indicators will help to see a trend between them. When the first indicator grows and surpasses the second one, it means that something negative is happening in the economy.

$$
\text { The newly established business index }=\frac{\text { Newly created entities }}{\begin{array}{l}
\text { Total number of entities } \\
\text { of the national economy }
\end{array}}
$$

The percentage values of the business insolvency index and the newly established business index for individual years are shown in Figure 10. At the beginning of the period considered, both the business insolvency index and the newly established business index values are high, at $14.71 \%$ and $26.53 \%$, respectively. Over the years since the transformation

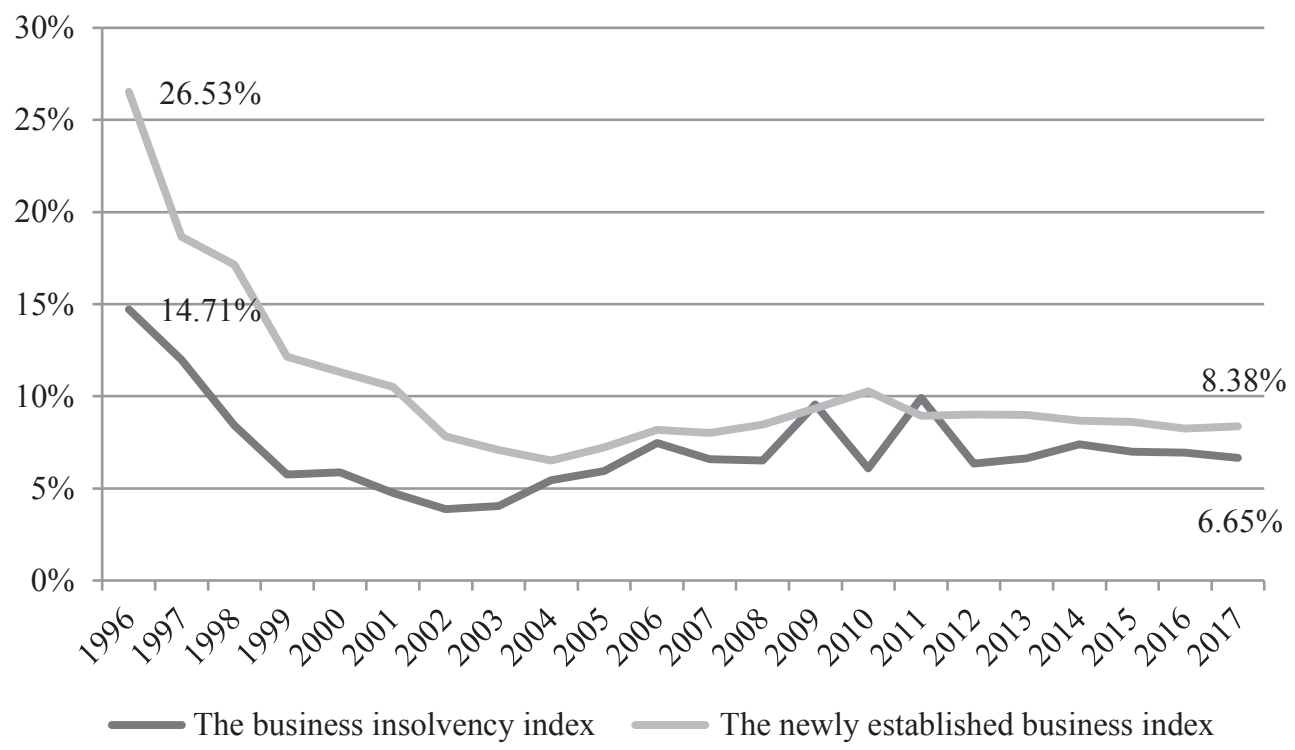

Fig. 10. The business insolvency index and the newly established business index in the period of 1996 to 2017

Source: own work based on data from [Central Statistical Office Reports]. 
of the economy, the value of the indicators has declined to $6.65 \%$ and $8.38 \%$.

In the analyzed period, only in 2009 and 2011 did the business insolvency index exceed the newly established business index. As mentioned before, this was due to how the register was updated. In the remaining years there is a positive relationship between the indicators, which means that the number of companies from year to year increased. It is worth emphasizing that in the reports of Central Statistical Office, the reasons for the deregistration of a company from the REGON register are not given. However, it seems that the reasons for the deregistration of companies from the register are important because there are many reasons for shutting down business, including the insolvency of an enterprise and the death of an entrepreneur. After a thorough analysis of the causes, the quality of this indicator can actually be assessed.

\section{Discussion}

The statistics on the number of bankrupt companies that take into consideration the number of operating companies in sectors and regions better reflect the degree of intensity of the bankruptcy of enterprises in each sector and individual region. However, the research sample is quite small. In the first test, the differences in the mean value were tested over a 14year period and in the second test an 18-year period. Consequently, the results may be questionable. The test should be repeated with a larger sample. Furthermore, the presented business insolvency index has some disadvantages, such as that it includes companies that have ceased operations for reasons other than financial ones and it does not cover all businesses that are economically bankrupt but which still operate in the market.

The presented subject matter is extremely important, especially when it comes to recognizing the causes that affect the elimination of companies from the market. The correct identification of changes taking place in the enterprise is essential. The right diagnosis of the situation of a company makes it possible to apply early actions (preventive measures), which can significantly protect the company from financial difficulties, and above all, overcome the risk of bankruptcy. Therefore, the next article will present and discuss the causes of business failure which were presented by various researchers from around the world.

\section{Conclusion}

It is very rare for a company with a good financial condition to submit an application for bankruptcy [Agarwal, Taffler 2008]. Companies have the opportunity to respond to the deteriorating financial condition by assessing it periodically.

The main purpose of this study was to analyze the statistics on the number of bankrupt companies by evaluating the significance of the differences between the values of indexes of the bankrupt businesses, bearing in mind the number of operating companies along with the values of the indexes which do not incorporate such figures. The statistical significance was checked using the t-Student test. Moreover, the study introduces the indicator of business insolvency and the indicator of newly established business.

Conclusions from the study of the literature:

- for the last 22 years (1996-2017) more than five million two hundred thousand companies have been removed from the REGON registry, but the number of records of bankruptcy cases does not exceed one hundred and sixteen thousand,

- the records of bankruptcy cases are 45 times lower than the number of closed-down companies from the REGON register in the analyzed period,

- it can be observed that there are cyclical fluctuations in the number of declared bankruptcies which are related to the economic situation,

- it was mostly manufacturing companies that filed for bankruptcy in the period of 2004-2017,

- the most frequently occurring bankruptcies were recorded in the Mazowieckie, Dolnośląskie and Śląskie regions in the last 18 years (2000-2017), and the highest number of bankrupt companies was reflected in the largest number of registered companies in each of them.

The following research questions were answered:

1. The differences that occurred in the values of the number of bankrupt companies in individual reports presented by various credit information agencies are statistically insignificant.

2. There is statistical significance between the values of the ratio of bankrupt firms in the relevant sector (manufacturing, services, retail, wholesale) to the general businesses operating in the sector and the values of the ratio bankruptcy of enterprises by sector (manufacturing, services, retail, wholesale), with the exception of the construction sector.

3. There is statistical significance between the values of the total percentage of bankrupt enterprises when taking into account the existing enterprises in the studied regions and the ratio of total share of bankrupt companies in each of them. 
Based on the study, the statement that the highest number of bankrupt companies was reflected in the largest number of registered companies in each of the regions is not true. This is because the highest number of bankrupt companies in relation to the operating companies is in the Dolnośląskie region $(8.56 \%$ of the total companies operating in the country). Most operating companies are in Mazowieckie $(18.78 \%$ of the total companies operating in the country). The confirmation of this statement is that there is a high ratio of bankrupt enterprises regarding the enterprises operating in the Warmińsko-Mazurskie region, where there is only $3 \%$ of the business population. Thus, it is crucial to bear in mind the relationship between the number of bankrupt companies and the number of companies operating locally. It is also important to take into account the specific nature of the region.

The business insolvency index and the newly established business index were presented in the article. In the opinion of the author, these indicators will better illustrate the number of insolvent companies. However, this is only a thesis that requires detailed research.

\section{Bibliography}

Agarwal V., Taffler R., 2008, Comparing the performance of market-based and accounting-based bankruptcy prediction models, Journal of Banking \& Finance, vol. 32, pp. 1541-1551.
Antonowicz P., 2015, Bankructwa i upadłości przedsiębiorstw. Teoria - praktyka gospodarcza, studia regionalne, UG, Gdańsk.

Central Statistical Office Reports, Structural Changes of Groups of the National Economy entities in the REGON Register, 2006-2017, http://stat.gov.pl (access: 13.03.2018).

Central Statistical Office, Industry Yearbooks, 2017, Yearbook of Industry Statistics, http://stat.gov.pl/ (access: 13.03.2018).

Coface, 2007-2017, Bankruptcy of Companies in Poland, http:// www.coface.pl/ (access: 13.03.2018).

Creditreform, Insolvencies in Europe, https://www.creditreform. de/ (access: 26.07.2018).

Euler Hermes, 2018, Bankruptcies, 2012-2017, http://www.eulerhermes.pl/ (access: 13.03.2018).

http://www.portal-bankrut.pl/informacja.php?kto=\&tytul=\&sekcja1=upadlosci/upadlosci_polska.php (access 25.05.2010).

KUKE, Bankruptcy of Companies in Poland, 2012-2017, http:// www.kuke.com.pl/ (access: 13.03.2018).

Mączyńska E., 2013, Syndrom hieny upadłościowej, http://www. pte.pl/ pliki/2/10/syndrom\%20hieny\%20upadlosciowej.pdf (access: 20.01.2013).

Ministry of Justice, Records of Cases in Common Courts by Law, 1990-2017, http://ms.gov.pl (access: 13.03.2018).

Nowara W., Szarzec K., 2004, Charakterystyka upadtości polskich przedsiębiorstw - wyniki badań, Zeszyty Naukowe AE w Poznaniu, no. 49.

The Bankruptcy Law, Act of 28 February 2003 with Subsequent Amendments.

The Restructuring Law, Act of 15 May 2015.

Tomczak S., 2014a, Comparative analysis of liquidity ratios of bankrupt manufacturing companies, Business and Economic Horizons, vol. 10, issue 3, pp. 151-164.

Tomczak S., 2014b, Comparative analysis of the bankrupt companies of the sector of animal slaughtering and processing, Equilibrium. Quarterly Journal of Economics and Economic Policy, vol. 3, pp. 59-86.

\section{DANE STATYSTYCZNE DOTYCZĄCE UPADLOŚCI PRZEDSIĘBIORSTW W POLSCE}

Streszczenie: Zjawisko upadłości przedsiębiorstw w Polsce pojawiło się dopiero po transformacji ustroju polityczno-gospodarczego, co nastąpiło na początku lat 90. (od momentu przekształcenia gospodarki centralnie sterowanej w gospodarkę rynkową). Od tej chwili to właśnie rynek stał się miejscem, gdzie dokonywana jest weryfikacja, czy przedsiębiorstwo będzie w stanie się utrzymać na nim, czy też nie, a skutkiem drugiej ewentualności może być jego upadłość. Upadłość można nazwać regulatorem, mającym na celu wyeliminowanie najsłabszych ogniw z rynku, co się wiąże z pozostawieniem na nim najsilniejszych podmiotów. W artykule przedstawiono wybrane dane statystyczne dotyczące upadłości przedsiębiorstw w Polsce w latach 1990-2017. Dane są prezentowane przez różne wywiadownie gospodarcze z podziałem na sektory oraz województwa, jednakże nie uwzględniają one stosunku liczby upadłych przedsiębiorstw do liczby tych działających. Na potrzeby artykułu obliczono dane statystyczne uwzględniające ten stosunek.

Słowa kluczowe: upadłość, dane statystyczne, przedsiębiorstwo, wskaźnik niewypłacalności przedsiębiorstw. 